\title{
High Pressure Processing Technology and Equipment Evolution: A Review
}

\author{
Wael M. Elamin ${ }^{* 1,2}$, Johari B. Endan ${ }^{1}$, Yus A. Yosuf ${ }^{1}$, Rosnah Shamsudin $^{1}$ and Anvarjon Ahmedov ${ }^{1}$ \\ ${ }^{1}$ Department of Process and Food Engineering, Faculty of Engineering, University Putra Malaysia, 43400 Serdang, Selangor, Malaysia \\ ${ }^{2}$ Biological and Agricultural Engineering, Faculty of Engineering, University of Khartoum, Khartoum, Sudan
}

Received 11 October 2015; Accepted 19 December 2015

\begin{abstract}
High pressure processing (HPP) is an interesting non-thermal technology that involves the sterilization of food by the mean of ultra-high pressures, which lead to extending the shelf life of processed food, as well as maintaining nutritional value and quality of food products. The consumers' increasing demand for this new products graped the interest of several already-existing high pressure equipment manufacturers around the globe. The successful of this technology encouraged them to enter the field of food processing and adjust their existing technologies to adapt to the new process. This review spots the major discoveries in HPP equipment history, describes the current applications of HHP in processing and provides comprehensive information about HPP equipment technology used in commercial and research applications. In addition, this paper presents the major manufacturers in HPP equipment industry around the world.
\end{abstract}

Keywords: High pressure processing, HPP equipment, HPP vessels

\section{Introduction}

High pressure processing (HPP) which is also known as ultra-high pressure (UHP) or high hydrostatic pressure (HHP) is a non-thermal food processing technology applied when the food is subjected to high hydrostatic pressure commonly at or above $100 \mathrm{MPa}$ [1-3]. This technology has been established to inactivate microorganisms and denature several enzymes, without flavour and nutrient degradation related to usual thermal processing treatments and other processing methods [4]. HPP has now been increasingly applied in the food production industry to produce high-quality food [5].

It was Certes in 1883 who was the first in history to relate the effects of high pressure on organisms [6]. However, the effect of high hydrostatic pressures on foods was first revealed at the end of 19th century by Bert Hite and co-workers in agricultural experiment station at West Virginia University, 1899. Hite used high hydrostatic pressure up to $600 \mathrm{MPa}$ as a tool to preserve milk [7], and later on vegetables and fruits in 1914 [8]. Later to these prime studies only a few works have been done, and no sustained research were published about high pressure processing until 1980's [2,9]. In mid-80's, the interest was resumed due to the successful growth of commercial HPP treatment as an alternative preservation method to traditional thermal processing of foods. In 1992, a Major revolution in HPP came in Japan by releasing the first high pressure processed product into market [10]. The pressure-treated jam unveiled to the food markets by one company at the beginning, subsequently created the remarkable success of

* E-mail address: wael_nesta@hotmail.com ISSN: 1791-2377 @ 2015 Kavala Institute of Technology. All rights reserved.
HPP when six other companies followed in the next three years [10]. Over the past 30 years, high pressure processing has been already effectively implemented in the food industry. Many studies have been performed to understand significant advances of HPP technology, which produced food products that are safe, fresh, nutritious, and innovative.

\section{High Pressure Processing Technology}

HPP is the application of uniform and even ultra-high pressures to the product from all sides within a few minutes. This method causes no damage or distorts to the foods as long as the treated product is not hollow or having an empty space inside. During the pressurizing time, a major reduction of microorganisms and a denaturation of proteins could occur without influencing molecular bonds. This process can inactivate the inappropriate bacteria, extend the shelf life of the product and provide an improvement to the criteria of the product. In addition, chemical reactions that cause the destruction of vitamins or produce off-flavours can be reduced under High-pressure conditions [4]. The general principles that explain the behaviour of foods under effects of high pressure include the Le Chatelier, Isostatic pressing, and microscopic-ordering principles.

Le Chatelier's Principle [11] states that a chemical system under equilibrium condition would experience a reaction change, accompanied by a decrease in volume when enhanced by pressure and vice versa $[3,12]$.

Isostatic Pressing (Pascal's Principle) the pressure is transmitted in a uniform manner in all directions. Following the decompression, the material returns to its initial shape $[3]$.

Microscopic Ordering Principle states that, at a constant temperature, increasing the pressure mutually increases the degree of ordering of the molecules of a substance. As a 
result, pressure, as well as temperature, exert antagonistic forces on molecular structure [13].

\section{High Pressure Processing Equipment}

History of High Pressure Equipment in Food Processing

The first high pressure food processing equipment was used to pressurize milk by Hite in 1899. As illustrated in figure 1, the equipment consists of a product container made of a collapsible tin tube where the milk was packed. This tube was closed tightly with a cap and placed inside a lead tube. Then it was filled with water, closed security with a lead lid, and positioned in a steel cylinder. A steel plug locked the bottom end of this cylinder. The cylinder was then placed between two steel blocks. By using a steel piston, pressure was applied to the lead tube and to the inside product accordingly [7]. This machine has been ordered from National Transit Company, Pennsylvania.
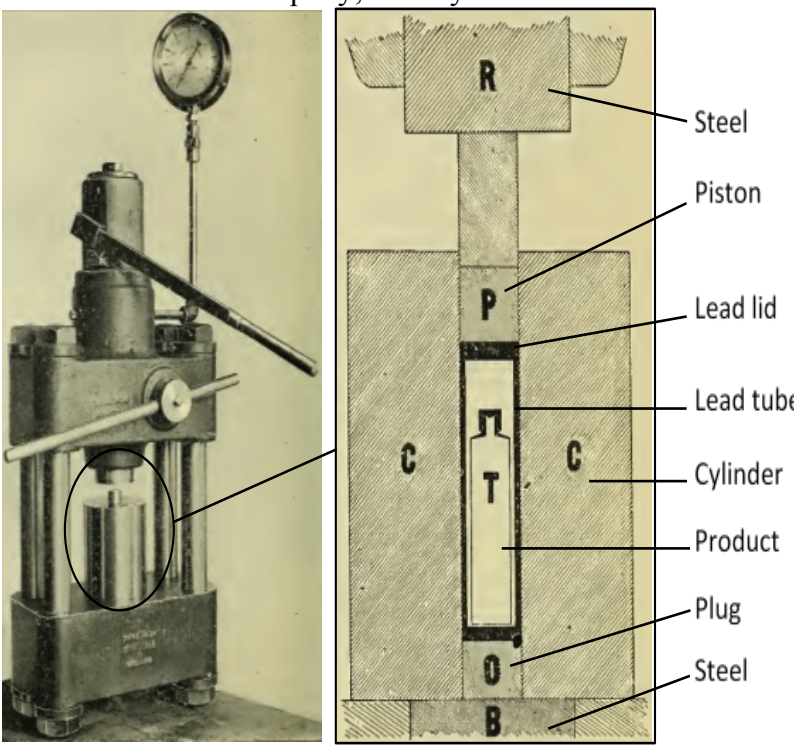

Fig. 1. First High Pressure Food Processing Equipment [7]

Although, the discovery of high pressure food processing and its effect on microbial inactivation was unleashed in 1899 by Hite and other researchers, the technology started to draw attention again after almost 100 years when a the commercial high pressure equipment came out in Japan in 1990 for the first time [14]. Mitsubishi Heavy Industries was the first to manufacture a high pressure vessel devoted to food processing [15]. This pressure vessel was fabricated of dual cylinders to decrease the fall of equipment lifetime due to continual use of the pressure vessel. The parts of the pressure vessel that are in contact with the pressure-transmitting fluid were designed to be made of stainless steel. The internal surface of the vessel is preloaded with a high compression stress, and it was set to work at pressures up to $700 \mathrm{MPa}$. Due to the fast pressurizing and depressurizing cycle, the maximum pressure was achieved in only $90 \mathrm{sec}$, a huge load is applied to the seal of the cap of the pressure vessel. Therefore, a self-seal packing with sufficient stiffness and durability was used. This seals can afford a repetition of opening/closing of the pressure vessel and compression process without a leakage (Figure 2).

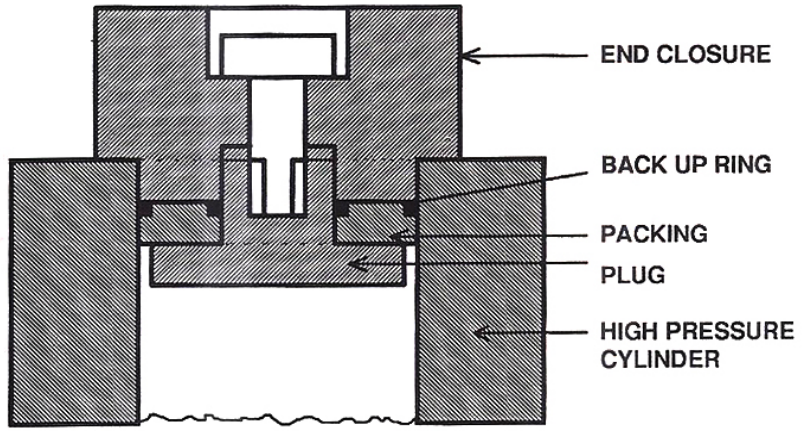

Fig. 2 A self-seal packing used in high-pressure vessel [15]

Following the Japanese revolution, HPP equipment technology was established gradually in other countries. The high cost of high pressure equipment was the main reason behind the late commercial spread of this technology [16]. Most of the equipment suppliers who have interest in developing HPP equipment for food sectors were in the first place high-pressure manufacturers of other applications like water-jet cutting and cold isostatic pressing. The manufacturers of the technology used in the metal and ceramics industries which closely resembles the food treatment followed suite [17].

\section{Commercial Application and Equipment of HPP}

The first HPP processed foods were launched in the Japanese market by developing a number of high pressure machines suitable for the food industry $[17,18]$. Companies that later perform these changes took the lead and became the first manufacturers of high-pressure food processing vessels. The leading Japanese companies that were manufacturing the vessels at that time besides Mitsubishi Heavy Industries Ltd. were Kobe Steel Ltd. and Nippon Steel Ltd. [15, 19]. Later, high pressure processed products were gradually introduced in other countries and subsequently other manufacturers of high pressure equipment began to appear in the market of HPP-treated foods. They include Engineered Pressure Systems, ABB Autoclave Systems Inc., ACB, NICK Corp., and Autoclave Engineers $[15,20]$.

The technique of HPP is currently successfully used in Japan, the United States and Europe for pasteurization of food products. The industrial application of HPP has been on an increasing trend for the last decade, as is evidenced by increased numbers of HPP equipment installations. Figure 3 presents the growing tendency of numbers of installation of HPP equipment, which exceeds 265 machines by 2014 [21]. High-pressure machine in 2014 had increased five times more than that produced ten years ago in 2004. The consumer market trends in these countries mentioned above regarding processed foods help to raise the number of implementation [22].

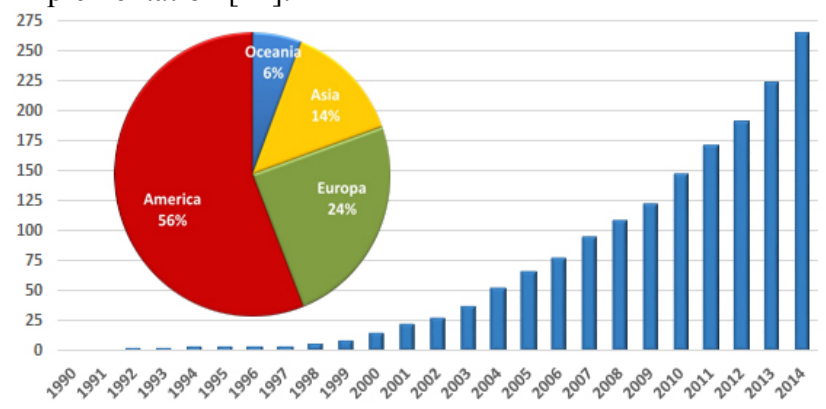




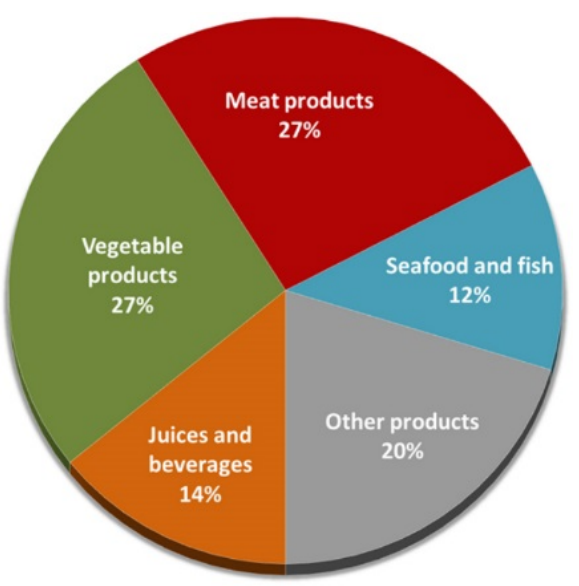

Fig. 3. Total number of HPP industrial machines in production until 2014 (left), and worldwide HPP food production in 2014 (right) [21]

On the other hand, numerous commercial food products had already benefitted from the HPP technology. At present days, HPP vegetable products, meat products, seafood, fresh fruits, and beverages are regularly sold in some markets throughout the developed world. Even so, HPP condiments, dressings, soups and sauces are already in the markets [22]. Figure 3 presents the categories of foods processed by HPP and its associated percentages. According to Flores [21], the worldwide HPP food production in 2014 exceeded 500 million $\mathrm{kg}$. Vegetables and meat take the lead with $27 \%$ each of the total, followed by juices and beverages with a $14 \%$ percentage. Seafood comes up with $12 \%$, and other products completed the table with a percentage near to $20 \%$. High-pressure technology is considered as an expensive method of food processing compared with traditional ways. The current equipment advances, successful commercialization of HPP products and a consumer demand for minimally processed safe and high-quality foods resulted in a significant research attention on HPP technology [23].

\section{Components of High Pressure Processing System}

The typical industrial high pressure system consist of a high pressure vessel, a pressure generation means, a temperature control device (optional), and a material handling system $[24,25]$.

\section{A. Pressure Vessels}

The pressure vessel is considered as the most important part of high hydrostatic pressure system. The first high pressure equipment used for food processing in 1899 by Hite, contains a built-in the vessel. Hite describes his first pressure vessel as a simple thick wall cylinder made from steel [7]. It was forged monolithic cylinder constructed in low alloy steel. The typical monolithic pressure vessel has wall thickness depends on the maximum working pressure of the vessel, the vessel diameter, and the number of cycles the vessel is designed to accomplish [25]. The working pressure is an essential parameter in validating the working lifetime. Decreasing the working pressure can reduce significantly the initial vessel price and the number of failures, which increases the vessel working time [26].

The wall thickness can be reduced by using pre-stressed designs $[25,27]$ as shown in figure 4 . Pre-stressed vessel technologies are preferred over a traditional mono-block design and currently used in a high pressure industry for the safe and reliable commercial size vessels operating at higher pressure levels [27]. The pre-tensioned vessels usually made from a multi-layer or wire-wounded high tensile steel alloy, with a closure system consisting of group of parts [25, 28].
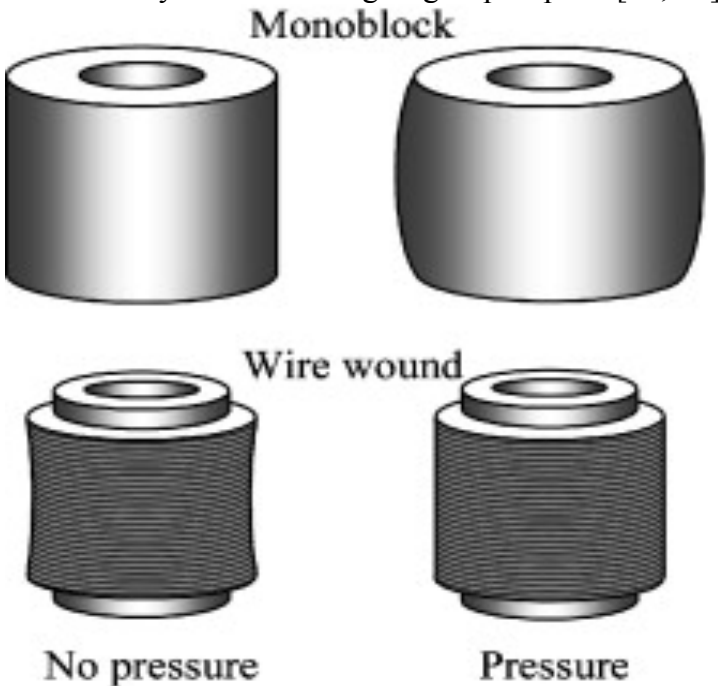

Fig. 4. Shows a possible reduction in pressure vessels wall thickness achieved by using a different pre-stressed design [23]

Designing of the pressure vessel is very critical, and many aspects should be considered during the design process. There are three most frequent designs to construct a pre-stressed cylindrical body of a pressure vessel, which depends on the operating pressure and diameter. These techniques are Autofrettage, Heat-shrink and Wire-wounded technique $[29,30]$, which presented in Figure 5. All of them sharing the core objective of an initial residual stresses in the inner core of the vessel [31].

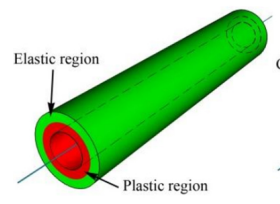

(a)

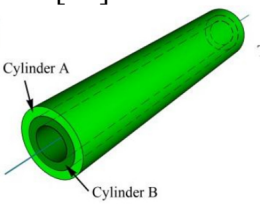

(b)

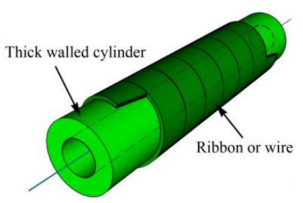

(c)
Fig. 5. Methods of reinforcing a thick walled cylinder, (a) Autofrettage cylinder, (b) Compound cylinder, and (c) Wire-wound cylinder [32]

\section{1) Autofrettage technique}

Autofrettage "self-shrinking" is a unique mechanical process of one cylinder pressure vessel resulting in pre-stressed condition after the process completion [33, 34]. Figure 5-a illustrates the Autofrettage process in two steps. First, a very high pressure is applied to the cylinder by either dragging a mandrel through the shell or by pumping oil into it. The innermost bore will experience a plastic deformation while the lesser stressed outside will expand elastically. The second step, when the pressure is released, the elastically deformed outside shell has the trend to regain its original shape but is prevented by the plastically deformed inside part [35]. The result is that the outer part of the shell pushes continuously onto the inside part resulting in the shell permanently in the pre-stressed condition [33].

2) Heat-shrink technique (multilayer vessel)

In this method, the vessel needs a minimum of two separate cylinders. Shrink fitting is carried out by heating up the external cylinder until it expands, and the inner cylinder is cooled until it shrinks. Then, the outer layer is assembled over the inner layer (Figure 5-b). The whole assembly is cooled until it reaches the room 
temperature, which results in residual hoop stresses putting the inner cylinder in compression [36]. In the vessel that is made especially for food processing typically, the innermost cylinder is stainless steel [30, 37].

3) Wire-wounded vessel

This technique combines a number of turns of high tensile strength wire wound around an inner cylinder at a continuously pre-stressed condition (Figure 5-c). During the process, the cylinder inner diameter will shrink because of the pressure from the wire, which leads to compressive residual stresses inside the vessel wall. Therefore, high tensile stresses will not increase while exposing to high internal pressure, granting wire-wounded vessels a great strength [38]. It is usually applied to increase strength to weight ratio and to improve the fatigue life $[28,30,39]$.

Vessels made by these techniques have a longer lifetime, durability, maximum pressure, and less weight of the shell. The wire-wounded vessel is similar to a multilayer vessel in that, it has an advantage of added safety with a leak before breaking construction. However, wire wound vessels have less weight than that of multilayer vessel of equal capacity [28]. The more interest of a wire winding technique is that the strength of the wire is independent of the wounded cylinder size. Therefore, the physical properties of the wire remain high. However, the wire-wounded vessel may have a very long life cycle and it can reach millions of cycles, compared with the inner cylinder which is considered to be limited [28]. Wire winding technology increases equipment costs and for that reason it is preferable for operations involving $600 \mathrm{MPa}$ and more [27].

\section{B. Pressure Generation Means}

Unlike straight processes such as thermal processing, the high-pressure process is independent of the equipment and processed food size and shape. The reason is that the pressure transmission is not mass/time dependent. Hence, reducing the processing time and scaling up the equipment from the laboratory to commercial size will not touch the efficiency of HPP. In contrast, it helps the HPP applications to develop faster. Two types of the compression processes, direct (piston) or indirect (pump) compression can achieve generation of high pressures in the pressure vessels (Figure $6)$.

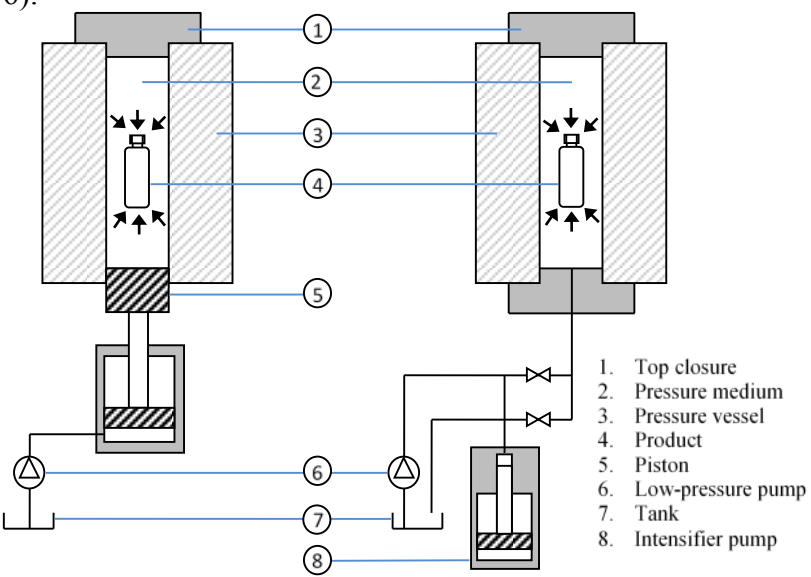

Fig. 6. Schematics of high-pressure food processing techniques direct (left) and indirect (right) compression.

\section{1) Direct compression}

This technique uses the vessel ends closure/s to act as a piston to build/release the pressure. This happens by reducing the specific volume inside the vessel until the desired pressure is reached [40]. Although, the direct system can achieve a rapid compression, the restrictions of the dynamic seal between the piston and the vessel obstruct the applications of this technique for a small-scale laboratory [41].

2) Indirect compression

Indirect compression is the method used in the application of much high pressure processing equipment in the food industry [20]. It employs a high-pressure intensifier pump to compress a pressure fluid from its reservoir tank into a pressure vessel, transmitted through high-pressure tubes. This technique is more appropriate for solids and high viscous liquid food [42]. This method also allows pressure to be released or kept constant at the required level during the treatment time for several minutes [43]

\section{Pressure-Transmitting Fluid}

Pre-packed products are loaded into the pressure vessel that must be filled with a fluid. This fluid works as a pressurizing medium, water in most current HPP equipment [4]. In case of liquid food, for example, the processing of juices or milk, the food will act as the pressure medium itself. The pressure vessel is filled with the liquid food, which will be compressed and then transferred to a reserving tank or directly to a filling line.

Pressure-transmitting fluids are used in the vessel to transfer pressure instantaneously and uniformly throughout the products [3]. This process is independent of the volume, size and shape of the product and pressure vessel $[18,44]$. The viscosity of the fluid under pressure is one of the factors that must be considered when selecting the fluid. The ability of the pressure-transmitting fluid to guard inner surface of a pressure vessel is important to prevent corrosion during the processing [45].

\section{Adiabatic Compression Heating}

Due to the compressive work against intermolecular forces, HPP causes temperatures to increase in the pressure vessel. This phenomenon is known as adiabatic heating [46]. According to first and second laws of thermodynamics, an adiabatic process arises without transfer of heat between a system and environment. The energy is transferred only as work [47, 48]. Change in the temperature of a pressure medium as a result of compression heating and subsequent heat transfer must be taken into account during HPP inactivation of bacterial spores $[49,50]$. Adiabatic compression can be specified as a compression or decompression processes that happen without any transfer of heat [51]. Equation 1 below expresses the adiabatic heating:

$\frac{d T}{d P}=\frac{T \alpha_{p}}{\rho C_{p}}$

In this equation the temperature increase, $\mathrm{dT}$ depends on the volumetric expansion coefficient $\alpha \_p$, the density $\rho$, the isobaric heat capacity of the material $\mathrm{C}$ pand the initial temperature $\mathrm{T}[50]$.

The act of compression during high pressure processing will raise the temperature of both the product and the compression fluid adiabatically about $3{ }^{\circ} \mathrm{C}$ for every 100 MPa [52]. Solid metallic materials of the pressure vessel do not experience the significant compression heating [51]. However, in fact, all compressible materials inside the pressure vessel change their temperature during 
compression. As a result, the temperature change in the process may differ depending on the composition of the food $[53,54]$. Table 1 illustrates temperature changes of certain substances due to adiabatic heating while Table 2 presents the temperature change of different pressure transmitting mixtures.

In the majority of the existing high-pressure equipment, the pressure vessel is made of steel. Due to low increasing level of temperature of steel during pressurization $\left(\sim 0^{\circ} \mathrm{C} / 100\right.$ $\mathrm{MPa})$, the vessel temperature following the decompression will be lower than that in processed product [56]. Due to heat transfer between the product and the vessel wall, the product parts that are in contact with the wall will be cooled down. In this condition, these parts will not reach the similar final temperature to that been attained in the core of the pressure vessel $[57,58]$.

\section{E. Packaging}

Table 1. Adiabatic heat of compression in various food systems [54]

\begin{tabular}{cc}
\hline Substances at $25{ }^{\circ} \mathbf{C}$ & $\begin{array}{c}\text { Temperature increase per 100 } \\
\text { MPa }\left({ }^{\circ} \mathbf{C}\right)\end{array}$ \\
\hline Water & $\sim 3.0$ \\
Orange juice & $\sim 3.0$ \\
Tomato salsa & $\sim 3.0$ \\
Salmon & $\sim 3.2$ \\
Chicken fat & $\sim 4.5$ \\
\hline
\end{tabular}

To preserve the food product from contamination by the pressurizing fluid, and to improve the processing efficiency the product is processed in its final form. The food and the package itself are processed mutually, so that the entire package remains protected until it reaches the final customer [59].

Table 2. Actual and predicted compression heating values of certain mixtures [55]

\begin{tabular}{ccccc}
\hline \hline Substance & $\begin{array}{c}\text { Initial } \\
\text { temp. }\left({ }^{\circ} \mathbf{C}\right)\end{array}$ & $\begin{array}{c}\text { Final } \\
\text { temp. } \\
\left({ }^{\circ} \mathbf{C}\right)\end{array}$ & $\begin{array}{c}\text { Predicted Experimental } \\
\text { temp. } \\
\text { Increase } \\
\left({ }^{\circ} \mathbf{C}\right)\end{array}$ & $\begin{array}{c}\text { temp. } \\
\text { Increase } \\
\left({ }^{\circ} \mathbf{C}\right)\end{array}$ \\
\hline 100\% Glycol & 24.2 & 52.3 & 28.1 & - \\
$75 \%$ Glycol & 26.3 & 54.5 & 28.1 & 25.1 \\
50\% Glycol & 24.5 & 44.5 & 20.0 & 22.0 \\
25\% Glycol & 24.4 & 41.5 & 17.2 & 19.2 \\
0\% Glycol + 100\% & 24.3 & 40.6 & 16.3 & - \\
Water & 24.0 & 68.5 & 44.5 & - \\
100\% Ethanol & 25.0 & 55.0 & 30.0 & 37.3 \\
75\% Ethanol & 26.0 & 50.0 & 24.0 & 30.4 \\
50\% Ethanol & 21.0 & 35.0 & 14.0 & 23.2 \\
25\% Ethanol & 24.0 & 40.6 & 16.3 & - \\
0\% Ethanol + 100\% & 24.3 & & & \\
Water & & & & \\
\hline \hline
\end{tabular}

In the selection of packaging material for high pressure processing, the accompanying elasticity that permits sufficient transmission of the pressure to the processed product, as well as ensuring a high sealing capability must be taken into account. The packaging employed for processing should be able to adjust to a $15 \%$ drop in volume, and then return to its first size and shape with no effect on sealing properties [59]. Plastic materials are accepted for HPP, although they are often not suitable for high-temperature processing associated with HPP. Metal canisters and glass wares are not appropriate for high pressure treatments [27]. Based on these facts, polymers or copolymers are considered the most suitable for HPP and commonly used as packaging materials [60]. The use of copolymer packaging films is most acceptable for HPP treatment based on their appropriate barrier properties. The tensile strength, vapour barrier permeability, oxygen permeability, heat seal strength and aroma permeability during HPP have been studied [61, 62]. However, no considerable changes were observed regarding the mechanical properties by pressure, neither thermal property was affected after pressurization [61, 62].

\section{HPP Operation Systems}

There are three major types of industrial high-pressure operating systems, a batch, continuous, and semi-continuous system $[2,17]$. However, high-pressure systems either batch or continuous are suitable for high-pressure pasteurization. The Batch mode has the advantage that can process both liquid and solid products, and in this case, products are usually pre-packed first. Whereas continuous and semi-continuous systems can be applied only to liquid or pumpable products [59].

\section{A. Batch system}

Equipment using batch high pressure treatment of foods usually consist of a cylindrical pressure vessel; end closure; a mean to fasten the end closure/s (e.g. yoke, threads); an intensifier pump which uses a low-pressure pump to supply the pressurizing fluid and essential system controls [27]. A medium (usually water) is poured into the pressure vessel while the food product is vacuum-packed in containers to prevent mixing.

In the operation of such system, the containers are loaded into the pressure vessel. As soon as they are loaded and closed, the vessel is filled with pressure transmitting fluid, by using a pressure generating mean. A pressure medium is pumped isostatically from its tank into the pressure vessel and once the desired pressure is reached, the pump is stopped by closing the inlet valves. The reduction ratio in volume is approximately $4 \%$ at a pressure of 100 $\mathrm{MPa}$ and a $680 \mathrm{MPa}$ pressure may cause a $15 \%$ reduction as well as compression of the liquid processed food.The desired pressure can be maintained with no more energy needed to hold it [63]. After holding the product for the required time, the pressure is released from the vessel by freeing out the pressure-transmitting fluid to return to its initial tank reservoir [2].

For most practices, products are held for 3-5 min at 600 MPa. Roughly, 5-6 cycles per hour are likely enough for loading, compression, holding, decompression, and unloading the product. After HPP, the treated product is discharged from the pressure vessel and forwarded to be stored in a conventional manner [3]. Batch processing removes any threat of contamination that can happen to food by lubricants or machine particles. Likewise, the equipment does not require cleaning during product changes, thus eliminates any danger of cross contamination [27].

\section{B. Continuous Processing Equipment}

Continuous processing is a subset of high pressure processing in which the liquid food are the only products that can be processed [64]. Figure 7 describes the continuous processing method. The products flow through an open-end tube system that pressurizes them at $100 \mathrm{MPa}$ or more by means of high-pressure intensifiers. After that, a mean to depressurize the product is applied in such way that avoids extreme shear and heating. Following the decompression, the processed liquid then goes to a sterile tank for final clean filling [17]. 


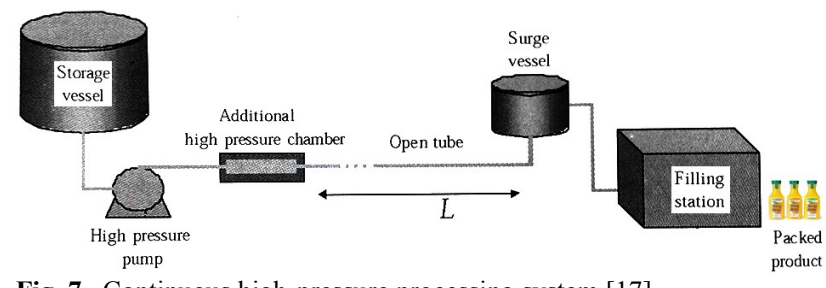

Fig. 7. Continuous high-pressure processing system [17]

In the previous process, when the fluid is passing through a pressure release component, it is actually subjected to shearing, cavitations and/or frictional effects depending upon the geometry of the component. The created high shear conditions can generate significant heat. These effects can contribute to microbial inactivation as well as changes in the functional properties of the treated fluid side by side with effects of the high pressure processing [65]. Thermal effects during depressurizing have often been difficult to separate from the anti-microbial contribution made by pressure [65]. Due to high shear forces, frictional heating, and other flow phenomena, this method had been replaced by Semi- continuous operations.

\section{Semi-Continuous Process Equipment}

Semi-continuous process systems (Figure 8) typically consists of several elements. In general, two or more pressure vessels, low-pressure pump to fill the vessels, high pressure transfer pump, holding and sterilized tanks and controlling valves [65]. The pressure vessels contain a free moving divider piston to separate the product from the pressurizing fluid. Controlling valves designed in which no cross contamination of the treated product with the upcoming untreated product [16].

The process starts by using a low-pressure pump to fill the pressure vessel with the liquid product. While the vessel is filling, the free piston is relocated. As soon as the food section is filled, the inlet valve is locked, and the pressurizing fluid is compressed into the vessel and moving the free piston to compress the liquid food. The reduction ratio is similar to that in a batch process. The vessel is depressurized after a suitable holding time. Freeing the pressure in the high-pressure side will decompress the food products and returns the piston to its initial position. The processed liquid product is discharged into a sterile reserve tank through a sterilized discharge end. A low-pressure pump is used to shift the free piston into the direction of the discharge port. Later, the processed liquid product is packed aseptically in sterilized containers [59].

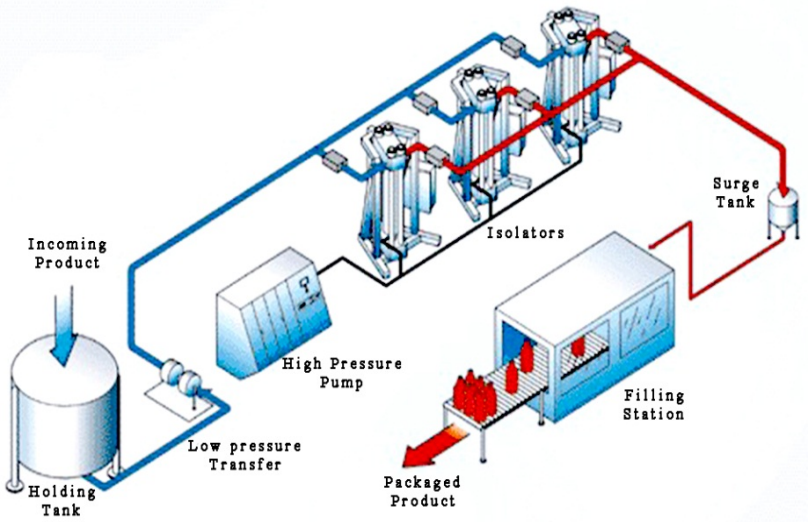

Fig. 8. Semi-continuous high-pressure processing system [66] semi-continuous system, three pressure vessels are used to provide a continuous product output. This production will be accomplished by operating the three vessels at the same time, one is loading, the second is compressing, and the last discharging at any point in time [67].

\section{Cycle Time}

Cycle time is paramount in the production process plan. Cycle time is referred to the total time of the process that includes the loading, closing the vessel, compression, holding, decompression and unloading [30]. The processing cycle time depends on the required pressure, which determines the processing time of the particular product. The size of the compressor can reduce the cycle time by speeding up the intensifiers. A typical production cycle time for a pasteurization process is only 3 to 8 minutes [68].

\section{HPP Global Manufacturers}

HPP equipment and services industry have been expanded and have spread globally. Since the 1990s, a number of equipment manufacturers have entered the high-pressure food industry, most of them starting from parallel sectors (such as water jet cutting and diamond manufacturing) with their experience. During that time, Japanese companies take the lead to convert into manufacturing of high-pressure equipment and vessels devoted to the food industry. Later, after the successful Japanese experience, many other manufacturers who have mastered the production of high pressure for numerous years followed their steps and entered the new market [19]. Some of these companies are yet in the industry while the rest have either disappeared from the scene or acquired by new enterprises.

At present, companies like HIPERBARIC and AVURE Technologies, which also rose on the shoulder of expert institutions, are dominating the market of HPP. There are also, some great partnerships like (MULTIVAC with UHDE) and (Fresher Evolution HPP with All Natural Freshness), which had combined their experience, resulting in great successes in the market. Table 3 states the major manufacturers in the HPP industry since 1990 and their main contributions to the HPP market.

\section{Economics of HPP}

The number of installed HPP equipment is increasingly rising since the mid-90s as shown in Figure 3. However, this number of HPP units is still small in comparison to the global demand, and this may be attributed to the high cost of investment in the technology. The cost of commercial-scale HPP unit ranged from 500,000 to over 2.5 million US Dollars, depending on the equipment capacity and the extent of automation used [30,69]. The total cost includes the variable costs (Labour, area, energy, utilities, maintenance and other) and the capital cost. Approximately $80 \%$ of the investment goes to the capital cost of the HPP system and installation. This capital cost are roughly divided into the pressure vessel and its components 50 60\%, pumping system 30 35\%, and controlling system with10 15\% [17]. While the processing cost can be estimated as follow, $65 \sim 75 \%$ for depreciation, energy $2 \sim 3 \%$, maintenance $22 \sim 33$ $\%$, and labor 10 40\% [70]. 
Table 3.Summary of the Main HPP Manufacturers in the Industry, and Their key Contributions to the Market

\begin{tabular}{|c|c|c|c|c|c|}
\hline Company & Country & Company Profile & Services & $\begin{array}{l}\text { Standard } \\
\text { Equip. size } \\
\text { (L, MPa) }\end{array}$ & Source \\
\hline $\begin{array}{l}\text { Mitsubishi } \\
\text { Heavy } \\
\text { Industries, } \\
\text { Ltd. }\end{array}$ & JP & $\begin{array}{l}\text { Established in } 1950 \text {, contributed to } \\
\text { Japanese HPP revolution in the } 90 \text { s } \\
\text { by manufacturing of the first } \\
\text { commercial HPP food-processing } \\
\text { vessel. }\end{array}$ & $\begin{array}{l}\text { Manufacturing and developing an } \\
\text { advanced HPP food processing } \\
\text { pressurizers and test systems. }\end{array}$ & - & $\begin{array}{l}\text { http://www.mhi.co.jp/ } \\
{[15]}\end{array}$ \\
\hline $\begin{array}{l}\text { Kobe Steel, } \\
\text { Ltd. }\end{array}$ & JP & $\begin{array}{l}\text { Incorporated in 1911, Starting } \\
\text { Research and development of } \\
\text { high-pressure technology and } \\
\text { producing jam, fruit juice and } \\
\text { unfrozen fruits back in the } 90 \mathrm{~s} \text {. }\end{array}$ & $\begin{array}{l}\text { Commercialize a High Pressure } \\
\text { Food Processor for Production Use. } \\
\text { Moreover, produce HPP Equipment } \\
\text { for Research And Development. }\end{array}$ & $\begin{array}{l}130 \mathrm{~L} \\
392 \mathrm{MPa}\end{array}$ & http://www.kobelco.co.jp/ \\
\hline $\begin{array}{l}\text { ABB } \\
\text { Pressure } \\
\text { Systems }\end{array}$ & SE & $\begin{array}{l}\text { Established on the } 1950 \text { s to } \\
\text { manufacture diamonds. In the } \\
\text { 1990s, it started interesting in HPP }\end{array}$ & $\begin{array}{l}\text { It was design and manufactured } \\
\text { innovative HPP equipment for } \\
\text { scientific research institutes. }\end{array}$ & 600 & $\begin{array}{l}\text { http://www.avure.com/ } \\
\text { http://www.flowwaterjet.com } \\
\text { / }\end{array}$ \\
\hline
\end{tabular}

of foods and became a leading

supplier of large ultra HPP systems

to the industry. Later, Flow

International in the US acquired it.

Flow US/SE Established in 1974 in Ultra HPP

International water-jet cutting. In 1993 started

interest in HPP of foods. Take over

ABB in 1999 under Flow Pressure

Systems, and patent the wire

winding technology of vessels and

yokes under Quintus trade name.

Later it established food

preservation market under the trade

name of Avure.

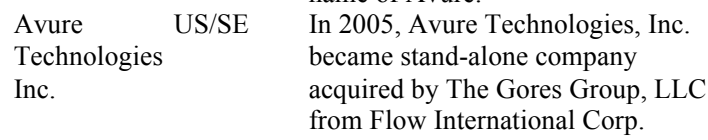

Flow Pressure Systems Co. was designing and manufacturing an advanced high-pressure equipment. Offered a safe and reliable hot and cold isostatic presses. /

Manufactures Vertically and from Flow International Corp.

horizontally oriented HPP

equipment batch systems, which

pasteurize and prepared ready-to-eat

foods.

ACB $\quad$ FR $\quad$ Basic experience in the field of

Pressure

hydraulic presses and metal

Developed a wide range of

http://www.acb-ps.com/

System

forming. In 1992 started design and manufacture of HPP equipment for both industrial and lab scale

Resato NL Since 1985 onwards, it has

high-pressure equipment, including Up to 700

specialized in developing and

manufacturing of high-pressure installations and components. The main expertise is as a supplier of waterjet cutting machines.

Elmhurst US It was incorporated since 1988; it Research was developing their systems and Inc. engineering it particularly for food applications. Patent the rotary HPP vessels.

interested in HPP equipment

development research.

Specialize in the design and Up to

manufacture of high-pressure $\quad 1,400$

http://www.resato.com/ components.

Deliver advanced high-pressure $22 \mathrm{~L}$

food processing equipment joined 689

with total science, process

technology, and engineering support.

Engineered BE/US Founded 40 years ago, Designs HPP

Pressure

systems for high-pressure

Offers Cold, Hot, Warm Isostatic

$100-900$

applications Proposes, various

Presses, also research,

manufacturing, testing, and upgrade

vessel designs, and offers industrial existing high-pressure equipment

and lab scale equipment.

Hiperbaric ES/US Initiated in 1999, since then it has

been involved in the design,

technological development,

production and commercialization of HPP equipment.

Stansted UK Established in 1970, specializing in Fluid Power manufacturing equipment for LTD. ultra-high pressure for industria fluid processing applications.

MULTIVAC DE Established since 1961, it becomes the lead manufacturer of the packaging solutions as well as packaging machines. MULTIVAC has entered a strategic partnership with UDHE in HPP solutions

Designs, manufactures, and markets $55 \sim 525 \mathrm{~L}$ HPP equipment all over the world, $600 \mathrm{MPa}$ with a manufacturing capacity of up to 50 HPP equipment per year. Also produces Hiperbaric 525 the biggest HPP system in the world.

Offer a full range of advanced $\quad 10 \mathrm{ml} 5 \mathrm{~L}$ high-performance laboratory \& pilot Up to 1,400 plant instruments for research \& development applications in HPP \& bioscience.

Offers package design, geometry, Single format, and packaging films. $\quad 55 \sim 350 \mathrm{~L}$ MULTIVAC also developed HPP Tandem process that reduces the damage to $2 \times 350 \mathrm{~L}$ packaging material. In addition, it is $600 \mathrm{MPa}$ providing industrial single, and tandem automated packaging lines.

Uhde High DE Established since 1930 to Develops and constructs of the manufacture HPP equipment for overall system of plants, from

http://www.elmhurstresearch. com/

http://www.epsi-highpressure .com/

http://www.nchyperbaric.com /

http://www.sfp-4-hp.demon.c o.uk/

http:/www.multivac.com/

http://www.uhde-hpt.com/ 


\begin{tabular}{|c|c|c|c|c|c|}
\hline Technologies & & $\begin{array}{l}\text { Ammonia Plants. Uses this } \\
\text { experience in HPP technologies } \\
\text { presently to develop plants used for } \\
\text { many applications. Offers } \\
\text { equipment for industrial and } \\
\text { research purposes. }\end{array}$ & $\begin{array}{l}\text { testing to handling. Including } \\
\text { designs and supplies all the essential } \\
\text { high-pressure components. }\end{array}$ & & \\
\hline $\begin{array}{l}\text { Baotou Kefa } \\
\text { Co. Ltd }\end{array}$ & $\mathrm{CN}$ & $\begin{array}{l}\text { Established in } 2001 \text {, focus on HPP } \\
\text { technology, cold sterilization, cold } \\
\text { isostatic pressing, HPP. }\end{array}$ & $\begin{array}{l}\text { Offers design development and } \\
\text { sales of Ultra HPP equipment for } \\
\text { industrial and scientific research } \\
\text { institutes. Designed, produced and } \\
\text { exported several HPP food products. }\end{array}$ & $\begin{array}{l}30 \sim 300 \mathrm{~L} \\
600 \mathrm{MPa}\end{array}$ & http://www.btkf.com/ \\
\hline $\begin{array}{l}\text { Fresher } \\
\text { Evolution } \\
\text { HPP }\end{array}$ & US & $\begin{array}{l}\text { Collaborated with All Natural } \\
\text { Freshness to design, develop, and } \\
\text { manufacture HPP machine. }\end{array}$ & $\begin{array}{l}\text { Designs and Patents a basket } \\
\text { Anti-Rotational Feature that prevent } \\
\text { product falling on the floor. }\end{array}$ & $\begin{array}{l}175 \sim 525 \mathrm{~L} \\
600 \mathrm{MPa}\end{array}$ & http://allnaturalfreshness.com \\
\hline UNIPRESS & PL & $\begin{array}{l}\text { Founded in } 1972 \text { focuses on HPP } \\
\text { studies of semiconductors. In } 1993 \text {, } \\
\text { UNIPRESS conducted the first } \\
\text { research program devoted to HPP. }\end{array}$ & $\begin{array}{l}\text { Designing advanced HPP lab units } \\
\text { for research institutes. }\end{array}$ & $\begin{array}{l}1.5 \mathrm{~L} \\
500 \mathrm{MPa}\end{array}$ & $\begin{array}{l}\text { https://www.unipress.waw.pl/ } \\
\text { food/en/?file=kop3.php/ }\end{array}$ \\
\hline
\end{tabular}

The cost per amount of treated product is still high for HPP. The range is from $10-20$ cents/L, where prices for traditional heat treatment can be only $2-4$ cents/L [17]. However, these prices start to reduce with an increase in demand for pressurized products. According to Bermúdez-Aguirre and Barbosa-Cánovas [71] the cost range of HPP treatment reduced to $8 \sim 22$ cents/L in 2011. Koutchma [30] also mention the same range in 2014, which make it suitable because of the premium quality offered by the technology [69]. The demands for HPP technology as a promising technique for increasing product shelf life and for delivering a healthy and quality food is growing very fast, because, the technology attracts a large group of consumers. If these demands are continue to raise with the same rate, in the coming years, the cost of production as well, the prices of HPP products will decrease further.

\section{Conclusion}

Advanced research in high pressure processing of foods and its application, has grown globally to enhance the efficiency of the process and expand new knowledge in this promising field. In the past 25 years, high pressure processing has promoted from being a laboratory preservation method to

\section{References}

1. R. Banerjee and A. Verma, "Minimally Processed Meat and Fish Products," in Minimally Processed Foods, M. W. Siddiqui and M. S. Rahman, Eds., ed New York: Springer International Publishing, 2015, pp. 193-250.

2. D. F. Farkas and D. G. Hoover, "High pressure processing," Journal of Food Science, vol. 65, pp. 47-64, 2000.

3. D. Yordanov and G. Angelova, "High pressure processing for foods preserving," Biotechnology \& Biotechnological Equipment, vol. 24, pp. 1940-1945, 2010.

4. N. Rastogi, "Introduction," in Recent Developments in High Pressure Processing of Foods, ed: Springer US, 2013, pp. 1-7.

5. V. Bansal, M. Siddiqui, and M. Rahman, "Minimally Processed Foods: Overview," in Minimally Processed Foods, M. W. Siddiqui and M. S. Rahman, Eds., ed New York: Springer International Publishing, 2015, pp. 1-15.

6. D. Knorr, "Hydrostatic Pressure Treatment of Food: Microbiology," in New Methods of Food Preservation, G. W. Gould, Ed., ed New York: Springer, 1995, pp. 159-175.

7. B. H. Hite, "The effect of pressure in the preservation of milk," Bull. West Virginia Univ. Agric. Exper. Stn., vol. 58, pp. 15-35, 1899.

8. B. H. Hite, N. J. Giddings, and C. E. Weakley, "Effect of pressure on certain micro-organisms encountered in the preservation of fruits and vegetables," West Virginia University Agricultural Experiment Station, vol. 146, pp. 2-67, 1914.

9. M. F. Patterson, M. Linton, and C. J. Doona, "Introduction to High Pressure Processing of Foods," in High pressure processing of become an economically useful technology.

Although, HPP technology has extremely many strong points in food processing since the 1990 s, there are still some gaps regarding the investment in this sector. HPP technology is very costly resulting in only a few companies with large capital investment to use it. This fact resulted in the delay of the spread of HPP technology among small food processors and even in some countries because of the incapability of high HPP investment. The inability to sell a large amount of equipment has forced some major manufacturers to market their services rather than their equipment. These manufacturers offer a charge payable permission toll system to food processors for applying a particular treatment to their food products without the need to purchase a full HPP unit [30].

Commercial benefits of HPP technology require more research to fill the gaps and to fully understand the process to reduce the production cost. With the continuous and gradually increasing demand of HPP equipment, new manufacturers will continue to appear. New innovative designs will be offered which will lead eventually to a reduction in the capital and operation costs. foods, C. J. D. a. F. E. Feeherry, Ed., ed Oxford: Blackwell Publishing Ltd, 2007, pp. 1-14.

10. D. Knorr, "Effects of high-hydrostatic-pressure processes on food safety and quality," Food Technology, vol. 47, pp. 156-161, 1993.

11. H. L. Le Chatelier, "A general statement of the laws of chemical equilibrium," Comptes Rendus, vol. 99, pp. 786-789, 1884.

12. H. Jaeger, K. Reineke, K. Schoessler, and D. Knorr, "Effects of Emerging Processing Technologies on Food Material Properties," in Food Materials Science and Engineering, ed New York: Wiley-Blackwell, 2012, pp. 222-262.

13. G. U. Benet, "High-pressure Low-temperature Processing of Foods: Impact of Metastable Phases on Process and Quality Parameters," $\mathrm{PhD}$ dissertation, Department of Food Biotechnology and Food Process Engineering, Berlin University of Technology, Berlin, 2005.

14. M. Yaldagard, S. A. Mortazavi, and F. Tabatabaie, "The principles of ultra high pressure technology and its application in food processing/preservation: A review of microbiological and quality aspects," African Journal of Biotechnology, vol. 7, pp. 2739-2767, 2008.

15. E. Palou, Nonthermal preservation of foods vol. 82. New York: CRC Press, 1997.

16. A. T. Balci and R. A. Wilbey, "High pressure processing of milkthe first 100 years in the development of a new technology," International Journal of Dairy Technology, vol. 52, pp. 149-155, 1999.

17. R. W. van den Berg, H. Hoogland, H. Lelieveld, and L. Van 
Schepdael, "High Pressure Equipment Designs for Food Processing Applications," in Ultra High Pressure Treatments of Foods, M. E. G. Hendrickx and D. Knorr, Eds., ed New York: Springer, 2001, pp. 297-313.

18. D. Farr, "High pressure technology in the food industry," Trends in Food Science \& Technology, vol. 1, pp. 14-16, 1990.

19. E. Palou, A. Lopez-Malo, G. Barbosa-Canovas, and B. Swanson, "High-Pressure Treatment in Food Preservation," in Handbook of Food Preservation, M. S. Rahman, Ed., ed New York: Basel: Marcel Dekker, 1999, pp. 533-575.

20. M. San Martin, G. Barbosa-Cánovas, and B. Swanson, "Food processing by high hydrostatic pressure," Critical Reviews in Food Science and Nutrition, vol. 42, pp. 627-645, 2002.

21. D. Flores, "High Pressure Processing (HPP) Technology as a Preservation Technique for Foods," presented at the AIRAPT-25th \& EHPRG-53rd, International Conference on High Pressure Science and Technology, Complutense University of Madrid, Madrid, Spain, 2015.

22. T. Bolumar, E. Georget, and A. Mathys, "High Pressure Processing (Hpp) of Foods and its Combination with Electron Beam Processing," in Electron Beam Pasteurization and Complementary Food Processing Technologies, Suresh Pillai and Shima Shayanfar, Eds., ed Cambridge: Woodhead Publishing, 2014, pp. 127-155.

23. J. A. Torres and G. Velazquez, "Commercial opportunities and research challenges in the high pressure processing of foods," Journal of Food Engineering, vol. 67, pp. 95-112, 2005.

24. C. J. Doona and F. E. Feeherry, "High Pressure Processing of Foods: Frontmatter," in High Pressure Processing of Foods, ed: Blackwell Publishing Ltd, 2008, pp. i-xxiii.

25. B. Mertens, "Hydrostatic Pressure Treatment of Food: Equipment and Processing," in New Methods of Food Preservation, ed New York: Springer, 1995, pp. 135-158.

26. L. Otero, A. D. Molina-Gaca,d P. D. Sanz, "Thermal effect in foods during quasi-adiabatic pressure treatments," Innovative Food Science \& Emerging Technologies, vol. 1, pp. 119-126, 6/1/ 2000

27. P. S. Rao, S. Chakraborty, N. Kaushik, B. Paul Kaur, and N. R. Swami Hulle, "High Hydrostatic Pressure Processing of Food Materials," in Introduction to Advanced Food Process Engineering, J. K. Sahu, Ed., ed London: CRC Press, UK, 2014, pp. 151-186.

28. H. Q. Zhang, G. V. Barbosa-Cánovas, V. B. Balasubramaniam, C. P. Dunne, D. F. Farkas, and J. T. Yuan, Nonthermal Processing Technologies for Food vol. 45. New Delhi: John Wiley \& Sons, 2011.

29. A. Mathur, "Pressure Vessels and Heat Exchangers," in Springer Handbook of Mechanical Engineering, K.-H. Grote and E. K. Antonsson, Eds., ed Berlin: Springer Berlin Heidelberg, 2009, pp. 947-966.

30. T. Koutchma, Adapting High Hydrostatic Pressure (Hpp) for Food Processing Operations. San Diego: Academic Press, 2014.

31. J. M. Alegre, P. Bravo, M. Preciado, and M. Solaguren-Beascoa, "Simulation procedure of high pressure vessels using the wire winding technique," Engineering Failure Analysis, vol. 17, pp. 61-69, 1// 2010.

32. A. Partovi and S. S. Shamili, "Analysis of Autofrettaged High Pressure Components," Master, Department of Mechanical Engineering, Blekinge Institute of Technology, Kalskrona, Sweden, 2012.

33. D.-S. Son, J.-H. Hong, and S.-H. Chang, "Determination of the autofrettage pressure and estimation of material failures of a Type III hydrogen pressure vessel by using finite element analysis," International Journal of Hydrogen Energy, vol. 37, pp. 12771-12781, 9// 2012.

34. J. $\mathrm{Hu}$ and $\mathrm{K}$. Chandrashekhara, "Fracture analysis of hydrogen storage composite cylinders with liner crack accounting for autofrettage effect," International Journal of Hydrogen Energy, vol. 34, pp. 3425-3435, 5// 2009

35. Anonymous. Whitepaper Autofrettage [Online]. Available: http://www.maximator-test.com/wp-content/uploads/2015/04/Max imator-Test-Autofrettage-2.pdf

36. D. R. Moss and M. Basic, "High Pressure Vessels," in Pressure Vessel Design Manual (Fourth Edition), D. R. Moss and M. Basic, Eds., ed Oxford: Butterworth-Heinemann, 2013, pp. 473-556.

37. G. Vetter, G. Luft, and S. Maier, "Design and construction of high-pressure equipment for research and production," in Industrial Chemistry Library, A. Bertucco and G. Vetter, Eds., ed Amsterdam: Elsevier, 2001, pp. 141-242.
38. S. Park and S. Jun, "Practical estimation of the in situ physical properties of foods under high pressure," Food Science and Biotechnology, vol. 24, pp. 777-782, 2015/06/01 2015.

39. M. Sedighi and A. Jabbari, "A new analytical approach for wire-wound frames used to carry the loads of pressure vessel closures," Journal of Pressure Vessel Technology, vol. 135, p. 061206, 2013

40. P. J. Fellows, "High-Pressure Processing," in Food Processing Technology, P. J. Fellows, Ed., Third ed New York: Woodhead Publishing, 2009, pp. 290-312.

41. L.-M. Aurelio, G. S. Barry, V. B.-C. Gustavo, and P. Enrique, "High-Pressure Treatment in Food Preservation," in Handbook of Food Preservation, Second Edition, M. S. Rahman, Ed., ed New York: CRC Press, 2007, pp. 815-853.

42. C. Hartmann, A. Delgado, and J. Szymczyk, "Convective and diffusive transport effects in a high pressure induced inactivation process of packed food," Journal of Food Engineering, vol. 59, pp. 33-44, 2003.

43. D. Knorr and V. Heinz, "Recent advances in high pressure processing of foods," New Food, vol. 2, pp. 15-19, 1999.

44. J. Torres, P. Sanz, L. Otero, C. Pérez Lamela, and M. Saldaña, "Engineering Principles to Improve Food Quality and Safety by High Pressure Processing," in Processing Effects on Safety and Quality of Foods, E. Ortega-Rivas, Ed., ed Florida: CRC Taylor \& Francis, Inc., 2009, pp. 379-414.

45. E. Hogan, A. Kelly, and D. Sun, "High pressure processing of foods: An overview," Food Science and Technology, vol. 1, pp. $1-27,2005$.

46. K. Knoerzer, R. Buckow, P. Sanguansri, and C. Versteeg, "Adiabatic compression heating coefficients for high-pressure processing of water, propylene-glycol and mixtures-A combined experimental and numerical approach," Journal of Food Engineering, vol. 96, pp. 229-238, 2010.

47. B. Zohuri and P. McDaniel, "First Law of Thermodynamics," in Thermodynamics In Nuclear Power Plant Systems, ed New York: Springer International Publishing, 2015, pp. 85-130.

48. J. Kestin, The Second Law of Thermodynamics. Michigan: Dowden, Hutchinson \& Ross, 1976.

49. S. Balasubramanian and V. Balasubramaniam, "Compression heating influence of pressure transmitting fluids on bacteria inactivation during high pressure processing," Food Research International, vol. 36, pp. 661-668, 2003.

50. P. Juliano, K. Knoerzer, and G. V. Barbosa-Cánovas, "High pressure thermal processes: thermal and fluid dynamic modeling principles," Engineering Aspects of Thermal Food Processing, vol. 1, pp. 93-161, 2009.

51. T. Koutchma, "Design for High-Pressure Processing," in Handbook of Food Process Design, J. Ahmed and M. Shafiur Rahman, Eds., ed Oxford: Wiley-Blackwell, 2012, pp. 998-1030.

52. J. Cheftel, "High Pressure and Biotechnology," in High Pressure and Biotechnology, C. Balny, R. Hayashi, K. Heremans, and P. Masson, Eds., ed Paris: INSERIM/Libbey Eurotext Ltd, Montrouge, 1992, pp. 195-209.

53. E. Patazca, T. Koutchma, and V. Balasubramaniam, "Quasi-adiabatic temperature increase during high pressure processing of selected foods," Journal of Food Engineering, vol. 80, pp. 199-205, 2007

54. E. Ting and V. Balasubramaniam, "Determining thermal effects in high-pressure processing," Food Technology, vol. 56, pp. 31-35, 2002.

55. V. Rasanayagam, V. Balasubramaniam, E. Ting, C. Sizer, C. Bush, and $\mathrm{C}$. Anderson, "Compression heating of selected fatty food materials during high-pressure processing," Journal of Food Science, vol. 68, pp. 254-259, 2003.

56. W. B. de Heij, L. Van Schepdael, R. Moezelaar, H. Hoogland, A. M. Matser, and R. W. van den Berg, "High-pressure sterilization: Maximizing the benefits of adiabatic heating," Food Technology, vol. 57 , pp. 37-41, 2003

57. W. De Heij, L. Van Schepdael, R. Van Den Berg, and P. Bartels, "Increasing preservation efficiency and product quality through control of temperature distributions in high pressure applications," International Journal of High Pressure Research, vol. 22, pp. 653-657, 2002.

58. L. Otero and P. D. Sanz, "Modelling heat transfer in high pressure food processing: a review," Innovative Food Science \& Emerging Technologies, vol. 4, pp. 121-134, 6// 2003.

59. E. Hogan, A. L. Kelly, and D.-W. Sun, "High Pressure Processing of Foods: An Overview," in Emerging Technologies for Food 
Processing, D.-W. Sun, Ed., ed London, UK: Elsevier Academic, 2014, pp. 3-24.

60. T. Norton and D.-W. Sun, "Recent advances in the use of high pressure as an effective processing technique in the food industry," Food and Bioprocess Technology, vol. 1, pp. 2-34, 2008.

61. M. Galotto, P. Ulloa, D. Hernández, F. Fernandez-Martin, R. Gavara, and A. Guarda, "Mechanical and thermal behaviour of flexible food packaging polymeric films materials under high pressure/temperature treatments," Packaging Technology and Science, vol. 21, pp. 297-308, 2008.

62. A. Le-Bail, N. Hamadami, and S. Bahuaud, "Effect of highpressure processing on the mechanical and barrier properties of selected packagings," Packaging Technology and Science, vol. 19, pp. 237-243, 2006.

63. H.-W. Huang, C.-P. Hsu, B. B. Yang, and C.-Y. Wang, "Potential utility of high-pressure processing to address the risk of food allergen concerns," Comprehensive Reviews in Food Science and Food Safety, vol. 13, pp. 78-90, 2014

64. V. M. Balasubramaniam, S. I. Martínez-Monteagudo, and R. Gupta, "Principles and application of high pressure-based technologies in the food industry," Annual Review of Food Science and Technology, vol. 6, pp. 435-462, 2015.

65. G. A. Cavender, "Continuous High Pressure Processing of Liquid Foods: An Analysis of Physical, Structural and Microbial Effects," $\mathrm{PhD}$ Thesis, Department of Food Science and Technology, University of Georgia, Georgia, 2011.

66. V. M. Balasubramaniam, "High Pressure Food Preservation," in Encyclopedia of Agricultural, Food, and Biological Engineering. vol. null, D. Heldman, Ed., ed New York, USA: Marcel Dekker Inc., Taylor \& Francis, 2007, pp. 490-496.

67. V. Balasubramaniam, D. Farkas, and E. J. Turek, "Preserving foods through high-pressure processing," Food Technology, vol. 62, pp. $32-38,2008$.

68. L. Wang, "Integration of Food Process Engineering and Food Microbial Growth," in Handbook of Food Safety Engineering, D.-W. Sun, Ed., ed New York: Wiley-Blackwell, 2011, pp. 153-175.

69. F. Sampedro, A. McAloon, W. Yee, X. Fan, and D. J. Geveke, "Cost Analysis and Environmental Impact of Pulsed Electric Fields and High Pressure Processing in Comparison with Thermal Pasteurization," Food and Bioprocess Technology, vol. 7, pp. 1928-1937, 2014/07/01 2014.

70. C. Tonello, "Case Studies on High-Pressure Processing of Foods," in Nonthermal processing technologies for food, B.-C. G. Zhang HQ, Balasubramaniam VM, Dunne CP, Farkas DF, Yuan JTC, Ed., ed New Delhi: IFT Press and Wiley-Blackwell, 2011, pp. 36-50.

71. D. Bermúdez-Aguirre and G. V. Barbosa-Cánovas, "An update on high hydrostatic pressure, from the laboratory to industrial applications," Food Engineering Reviews, vol. 3, pp. 44-61, 2011. 